\title{
Comparative Nephroprotective Effects of Extracts of Buchholzia coriacea on some Biochemical Parameters in Carbon Tetrachloride-induced Toxicity in Rattus novergicus
}

\author{
Godwin C. Ugwu, Chinagorom L. Okanya, J ude V. Egbuji, J ude I. Okwo, \\ Emmanuel I. Nnamonu and J oseph E. Eyo
}

Department of Zoology and Environmental Biology, University of Nigeria, Nsukka, Nigeria, Enugu State, Nigeria

(Received: August 30, 2018; Accepted: October 23, 2018; Published (web): December 10, 2018)

\begin{abstract}
Buchholzia coriacea (wonderful kola) is a medicinal plant that has been used worldwide as an alternative medication to promote human health. Comparative nephroprotective effects of crude seed powder, aqueous and methanolic extracts of $B$. coriacea in hepatotoxic rats was investigated for 56 days. The crude powder (BCCP), aqueous extract (BCAE) and methanolic extract (BCME) significantly reduced $(\mathrm{p}<0.05)$ the levels of creatinine and uric acid and decreased minimally throughout the treatment periods. Total protein increased significantly $(\mathrm{p}<0.05)$. Significant decrease $(\mathrm{p}<0.05)$ were observed with $200 \mathrm{mg} / \mathrm{kg}$ BCAE and BCCP respectively in urea and BUN levels. Noticeable nephroprotective effects may be attributed to the presence of phytochemicals like flavonoids and tannins which act as antioxidants. This study has demonstrated that $B$. coriacea crude seed powder, methanolic and aqueous extracts caused no adverse effect on the rat kidney and may be recommended for the management of nephrotoxicity.
\end{abstract}

Key words: Nephroprotective, Crude seed powder, Buchholzia coriacea, Albino rats.

\section{INTRODUCTION}

Medicinal plants have been of immense benefit to man in the management of diseases as they are cheaper, affordable and in some cases give better therapeutic value than synthetic drugs. The plant Buchholzia coriacea was named after a herpetologist "Reinhold Wilhelm Buchhoz" who collected the plant in Cameroon in late $19^{\text {th }}$ century. ${ }^{1}$ It belongs to the family Capparadaceae. It is a tree, evergreen, with a dense crown, large glossy leathery leaves arranged spirally and clustered at the ends of the branches, and conspicuous cream-white flowers in racemes at the end of the branches. It grows to about $20 \mathrm{~m}$ in height. The fruits are large, long-stalked, ellipsoid, resembling avocado pears, endocarp up to $1.3 \mathrm{~cm}$ thick and woody, yellowish when ripe, flesh yellow,

Correspondence to: Joseph Eyo

E-mail: <joseph.eyo@unn.edu.ng>; Tel: +234 8026212686

Dhaka Univ. J. Pharm. Sci. 17(2): 227-235, 2018 (December)

DOI: http://dx.doi.org/10.3329/dujps.v17i2.39180 edible, containing a few large blackish seeds about $2.5 \mathrm{~cm}$ long. ${ }^{2,3}$ The seeds are covered in purple aril which are chewed in Ivory Coast and has a sharp pungent taste and hot spicy flavour. ${ }^{4,5}$ It is also found mostly in Southern part of Nigeria, Ghana and Liberia. In Nigeria, B. coriacea is known as "Uworo" in Yoruba, "Owi" in Edo, "Uke" in Igbo and "Ovu" in Benin. Other common names include, musk tree in English and Aponmu in Akure. ${ }^{6}$ Among central Africans, the fruit is known as "esson bossi". $B$. coriacea has been proven to possess pharmacological and cosmetic effects. In African traditional medicine, B. coriacea is documented to possess diverse medicinal potential. Its leaves and seeds are reported scientifically to have good antibacterial ${ }^{6}$, anthelmintic ${ }^{8,9}$ antimicrobial, analgesic ${ }^{10}$, hypoglycaemic $^{11}$, abortifacient and cytotoxic effects. $^{12}$ The seed also acts as blood cleanser, facilitates learning ability and strengthens the 
nervous system. ${ }^{13}$ Fever, gonorrhoea and gastrointestinal infections are reported to have been locally treated with $B$. coriacea. $^{6,10,14}$ The use of wonderful kola plant parts in some traditional practices have been attributed to the fact that it is rich in secondary metabolites. ${ }^{6,10}$ Based on its diverse traditional use, the present study was designed to evaluate the comparative nephroprotective effects of aqueous and methanolic seed extracts of B. coriacea seed powder in carbon tetrachloride-induced kidney damaged in Albino rats.

\section{MATERIALS AND METHODS}

Plant material and extracts preparation. The seeds of B. coriacea were purchased from local markets around Nsukka metropolis, Nsukka Local Government Area of Enugu State, Nigeria. The seeds were identified ${ }^{1}$ and authenticated by a taxonomist in Bioresources Development and Conservation Programme (BDCP), Nsukka, Enugu State, Nigeria and a voucher specimen number (INTERCEDD/ 709) was deposited in the BDCP herbarium. They were cut into small pieces, air dried at room temperature for 4 weeks and pulverized into fine powder using a grinding machine (Honda: model 622, China).

The method of extraction followed that of Okere and others. ${ }^{15}$ About $200 \mathrm{~g}$ and $800 \mathrm{~g}$ of the powdered seeds were soaked in $500 \mathrm{ml}$ of water and $700 \mathrm{ml}$ of methanol respectively for 48 hours with intermittent shaking. The soaked substances were filtered using Whatman number one filter paper and concentrated using rotary evaporator at $60^{\circ} \mathrm{C}$. The concentrated sample were further subjected to dryness using hot air oven set at $50^{\circ} \mathrm{C}$ and then stored in an airtight bottle in a refrigerator for subsequent use. The crude powder were obtained by passing the ground powder samples through muslin cloth $(0.7 \mu \mathrm{m}$ mesh size). The aqueous and methanolic extracts gave 19.18 and $5.17 \%$ yield, respectively.

Drugs and chemicals. Silymarin tablets (Silybon-140®), used in this study was purchased from Micro Labs Limited, Himachal Pradesh, India. All the reagents and chemicals used in the study were of analytical grade. Diagnostic kits for the estimation of serum levels of various parameters were procured from Randox Laboratory Limited, United Kingdom.

Procurement and management of experimental animals. One hundred and fourty four adult male rats $(150-200 \mathrm{~g})$ were purchased from Genetics and Animal Breeding Unit, Department of Zoology and Environmental Biology, University of Nigeria, Nsukka. The rats had no history of drug consumption and were kept in stainless wire-rat cages equipped with drinkers and fecal collecting trays, in a clean and fly proof experimental animal house. The rats were fed commercial growers chick mash (18\% crude protein) made by Vital Feeds, Nigeria Limited and pore table water ad libitum and allowed to get acclimatized for 14 days before the start of the experiment. The fecal droppings in the tray were removed daily. All procedures in this study conformed to the guiding principles for research involving animals as recommended by the Committee and the International Guidelines for Handling of Laboratory Animals. ${ }^{16}$

Induction of hepatotoxicity in male rats. In this study, hepatic injury in male rats from all the groups except standard control was induced by single oral administration of $150 \mathrm{mg} / \mathrm{kg}$ bw of $20 \% \mathrm{CCl}_{4}$ mixed with olive oil as vehicle in 1:1 ratio. Animals with hepatic injury were post treated with extract of crude seed powder, aqueous and methanolic seed extracts of $B$. coriacea. The extracts were given at the prescribed doses (200-400-and $800-\mathrm{mg} / \mathrm{kg}$ bw) orally with the help of gastric tube.

Experimental design. The procured albino rats were randomly assigned into four major groups (A, $\mathrm{B}, \mathrm{C}$ and $\mathrm{D}$ ) in a completely randomized block design having 36 rats per group. Group A, B, C and D represented the control group, aqueous extract group, methanolic extract group and crude powder group, respectively. The major groups $\mathrm{A}, \mathrm{B}, \mathrm{C}$ and $\mathrm{D}$ were further divided into 3 sub-groups each (A1, A2 and A3), (B1, B2 and B3), (C1, C2 and C3) and (D1, D2 and D3) of 12 rats per group, respectively. Each subgroup was divided into 3 replicates of 4 rats per replicate. Control groups (A1, A2 and A3) served as 
the normal control group, positive and negative control groups respectively. The normal control was not intoxicated but was given $1 \mathrm{ml} / \mathrm{kg}$ body weight (bw) of normal saline; positive control was intoxicated with $150 \mathrm{mg} / \mathrm{kg}$ bw of $20 \% \mathrm{CCl}_{4}$ dissolved in olive oil as stated by Manikandaselvi et $a l .{ }^{17}$ and treated with standard drug (Silymarin 200 $\mathrm{mg} / \mathrm{kg} \mathrm{BW}$ orally), while negative control group was intoxicated with oral administration of $150 \mathrm{mg} / \mathrm{kg}$ bw of $20 \% \mathrm{CCl}_{4}$ in olive oil and were given $1 \mathrm{ml} / \mathrm{kg}$ body weight of normal saline. The rats in experimental groups B (aqueous extract group), C (methanolic extract group) and D (crude seed powder group) were intoxicated with $150 \mathrm{mg} / \mathrm{kg}$ of $20 \%$ $\mathrm{CCl}_{4}$ in olive oil and treated with graded doses of $200-400$ and $800-\mathrm{mg} / \mathrm{kg}$ bw of B. coriacea, respectively. All treatment commenced after seven days of intoxication to allow for establishment of hepatotoxicity. The standard drug and the $B$. coriacea seed extracts were administered once daily orally for 56 days (eight weeks).

Collection of blood sample. Blood samples were collected from each group on the seventh day pre-treatment and at two weeks intervals during treatment. The blood samples were collected from the retro-orbital plexus of the anesthesized rats as described by Hoff ${ }^{18}$ and was allowed to clot and then centrifuged at $4000 \mathrm{rpm}$ for 20 minutes. Thereafter, the supernatant (serum) was carefully separated using droping pipette and used to determine various biochemical parameters.

Determination of kidney function markers. The effects of crude seed powder, aqueous and methanolic extracts of $B$. coriacea on carbon tetrachloride-induced kidney damage on kidney function markers were determined using the methods of Folin $^{19}$ for urea and uric acid, Peters ${ }^{20}$ for creatinine, Kaplan $^{21}$ for blood urea nitrogen (BUN) and $\operatorname{Sood}^{22}$ for total protein. All determinations were done using the diagnostic test kits commercially prepared by Randox Laboratory Limited, United Kingdom.

Statistical analysis. Data obtained were statistically analysed for the effect of treatment and duration using one-way analysis of variance (ANOVA) while Duncan's Multiple Range Test (DMRT) was used to separate significant treatment means. The level of significance was set at $\mathrm{p} \leq 0.05{ }^{23}$ The results were tabulated as mean $\pm \mathrm{SEM}$.

\section{RESULTS AND DISCUSSION}

Effects of graded doses of crude seed powder, aqueous and methanolic extracts of $B$. coriacea on creatinine level of hepatotoxic rats. A duration dependent significant reduction $(\mathrm{p}<0.05)$ in creatinine level of $\mathrm{CCl}_{4}$-induced toxic rats was observed in all the doses $(200,400$ and $800 \mathrm{mg} / \mathrm{kg}$ ) of B. coriacea crude seed powder, aqueous, methanolic extracts and positive control from week two till the end of the experiment when compared with the normal and negative control (Table 1). However, the normal control group produced no significant differences throughout the period of treatment and was significantly lower $(\mathrm{p}<0.05)$ when compared with all other groups at each duration. On the effects of treatment, there were significant increase $(\mathrm{p}<$ 0.05 ) in creatinine levels of animals in silymarin, $\mathrm{CCl}_{4}$, crude seed powder, aqueous and methanolic extract groups when compared with the normal control at week 0 (Table 1), while no significant differences $(p>0.05)$ were observed from week 2 to 8 when compared with the control except the Negative control that were significantly high $(\mathrm{p}<$ 0.05) than BCAE, BCME and BCCP groups throughout the duration of the study when compared with the normal and positive control (Table 1).

Effects of graded doses of crude seed powder, aqueous and methanolic extracts of $B$. coriacea on urea level of hepatotoxic rats. The urea levels were significantly high $(\mathrm{p}<0.05)$ in the negative control groups throughout the duration of the study (from week 2 to 8) compared to BCAE, BCME and BCCP group (Table 2). Similarly, the normal control group produced no significant differences throughout the period of treatment. However, a duration dependent significant reduction $(\mathrm{p}<0.05)$ was observed in urea level of positive control and rats given $200 \mathrm{mg} / \mathrm{kg}$ $\mathrm{BCAE}$ at week 2 , and then decreased minimally from 
week 4 to 8 when compared with the normal control and negative control. BCME produced no significant difference throughout the period of study when compared with the control, while BCCP significantly reduced $(\mathrm{p}<0.05)$ the urea level at $200 \mathrm{mg} / \mathrm{kg}$ from week 2 to 8 when compared with the positive

Table 1. Effects of graded doses of crude seed powder, aqueous and methanolic extracts of $B$. coriacea on creatinine level of hepatotoxic rats.

\begin{tabular}{|c|c|c|c|c|c|c|}
\hline \multirow[t]{2}{*}{ Treatments } & \multirow[t]{2}{*}{ Dosage } & \multicolumn{5}{|c|}{ Creatinine (mg/dl) } \\
\hline & & Week 0 & Week 2 & Week 4 & Week 6 & Week 8 \\
\hline Normal control & $1 \mathrm{ml} / \mathrm{kg}$ Normal saline & $0.74 \pm 0.17^{\mathrm{a} 1}$ & $0.74 \pm 0.15^{\mathrm{a} 1}$ & $0.81 \pm 0.09^{\mathrm{a} 1}$ & $0.73 \pm 0.04^{\mathrm{a} 1}$ & $0.73 \pm 0.06^{\mathrm{al}}$ \\
\hline Positive control & 200 mg/kg Silymarin & $9.26 \pm 0.91^{\mathrm{cd} 3}$ & $3.29 \pm 0.59^{\mathrm{ab} 2}$ & $0.92 \pm 0.15^{\mathrm{a} 1}$ & $0.93 \pm 0.02^{\mathrm{al}}$ & $0.67 \pm 0.82^{\mathrm{a} 1}$ \\
\hline Negative control & $150 \mathrm{mg} / \mathrm{kg} \mathrm{CCl}_{4}$ & $8.74 \pm 1.44^{\text {bcd } 1}$ & $8.27 \pm 2.84^{\mathrm{c} 1}$ & $8.96 \pm 2.38^{\mathrm{b} 1}$ & $8.83 \pm 2.31^{\mathrm{b} 1}$ & $8.51 \pm 1.91^{\mathrm{bl}}$ \\
\hline \multirow[t]{3}{*}{$\mathrm{BCAE}$} & $200 \mathrm{mg} / \mathrm{kg}$ & $6.76 \pm 0.62^{\mathrm{bc} 2}$ & $1.96 \pm 1.06^{\mathrm{a} 1}$ & $0.99 \pm 0.05^{\mathrm{a} 1}$ & $0.81 \pm 0.01^{\mathrm{a} 1}$ & $0.62 \pm 0.10^{\mathrm{al}}$ \\
\hline & $400 \mathrm{mg} / \mathrm{kg}$ & $8.74 \pm 1.44^{\mathrm{bcd} 3}$ & $2.97 \pm 0.92^{\mathrm{ab} 2}$ & $0.79 \pm 0.00^{\mathrm{a} 1}$ & $1.05 \pm 0.03^{\mathrm{a} 1}$ & $0.72 \pm 0.04^{\mathrm{a} 1}$ \\
\hline & $800 \mathrm{mg} / \mathrm{kg}$ & $9.60 \pm 0.79^{\mathrm{d} 3}$ & $2.82 \pm 0.33^{\mathrm{ab} 2}$ & $1.33 \pm 0.01^{\mathrm{a} 1}$ & $0.86 \pm 0.02^{\mathrm{a} 1}$ & $0.72 \pm 0.04^{\mathrm{al}}$ \\
\hline \multirow[t]{3}{*}{ BCME } & $200 \mathrm{mg} / \mathrm{kg}$ & $8.53 \pm 1.33^{\mathrm{bcd} 2}$ & $0.65 \pm 0.18^{\mathrm{a} 1}$ & $0.95 \pm 0.17^{\mathrm{al}}$ & $1.10 \pm 0.01^{\mathrm{a} 1}$ & $0.69 \pm 0.12^{\mathrm{a} 1}$ \\
\hline & $400 \mathrm{mg} / \mathrm{kg}$ & $7.36 \pm 0.18^{\mathrm{bc} 4}$ & $1.32 \pm 0.06^{\mathrm{a} 3}$ & $0.87 \pm 0.12^{\mathrm{a} 2}$ & $0.77 \pm 0.07^{\mathrm{a} 12}$ & $0.46 \pm 0.03^{\mathrm{al}}$ \\
\hline & $800 \mathrm{mg} / \mathrm{kg}$ & $8.31 \pm 0.65^{\mathrm{bcd} 2}$ & $0.53 \pm 0.09^{\mathrm{a} 1}$ & $0.84 \pm 0.03^{\mathrm{al}}$ & $0.48 \pm 0.01^{\mathrm{al}}$ & $0.45 \pm 0.02^{\mathrm{al}}$ \\
\hline \multirow[t]{3}{*}{ ВCCP } & $200 \mathrm{mg} / \mathrm{kg}$ & $6.19 \pm 0.21^{\mathrm{b} 3}$ & $0.43 \pm 0.13^{\mathrm{a} 1}$ & $0.72 \pm 0.04^{\mathrm{a} 12}$ & $0.70 \pm 0.19^{\mathrm{a} 2}$ & $0.66 \pm 0.10^{\mathrm{al}}$ \\
\hline & $400 \mathrm{mg} / \mathrm{kg}$ & $6.62 \pm 0.24^{\mathrm{bc} 3}$ & $1.29 \pm 0.01^{\mathrm{a} 2}$ & $0.86 \pm 0.02^{\mathrm{a} 1}$ & $0.84 \pm 0.03^{\mathrm{a} 1}$ & $0.64 \pm 0.09^{\mathrm{al}}$ \\
\hline & $800 \mathrm{mg} / \mathrm{kg}$ & $8.07 \pm 0.51^{\mathrm{bcd} 2}$ & $0.76 \pm 0.02^{\mathrm{a} 1}$ & $0.75 \pm 0.03^{\mathrm{a} 1}$ & $0.77 \pm 0.07^{\mathrm{a} 1}$ & $0.65 \pm 0.08^{\mathrm{al}}$ \\
\hline
\end{tabular}

Values represent mean \pm SEM of 3 observations. Values with in the same column with different alphabet superscripts differ significantly (p $<0.05$ ) between different concentrations at the same exposure duration, while values on the same row with different numeric superscripts differ significantly $(\mathrm{p}<0.05)$ between different exposure periods within the same concentration. $\mathrm{NC}=$ Normal control, $\mathrm{SL}=$ silymarin positive control, $\mathrm{CCl}_{4}=$ Carbon tetrachloride negative control, $\mathrm{BCAE}=$ Buchholzia coriacea aqueous extract, $\mathrm{BCME}=$ Buchholzia coriacea methanolic extract, $\mathrm{BCCP}=$ Buchholzia coriacea crude powder.

Table 2. Effects of graded doses of crude seed powder, aqueous and methanolic extracts of B. coriacea on urea level of hepatotoxic rats.

\begin{tabular}{|c|c|c|c|c|c|c|}
\hline \multirow[t]{2}{*}{ Treatments } & \multirow[t]{2}{*}{ Dosage } & \multicolumn{5}{|c|}{ Urea $(\mathrm{mg} / \mathrm{dl})$} \\
\hline & & Week 0 & Week 2 & Week 4 & Week 6 & Week 8 \\
\hline Normal control & $1 \mathrm{ml} / \mathrm{kg}$ Normal saline & $27.16 \pm 1.16^{\mathrm{al}}$ & $27.30 \pm 3.97^{\mathrm{abcl}}$ & $27.34 \pm 2.21^{\mathrm{abcd} 1}$ & $27.84 \pm 1.72^{\mathrm{ab} 1}$ & $27.82 \pm 2.1^{\mathrm{bcl}}$ \\
\hline Positive control & 200 mg/kg Silymarin & $39.82 \pm 4.04^{\mathrm{c} 23}$ & $29.74 \pm 0.81^{\mathrm{al}}$ & $24.41 \pm 3.61^{\mathrm{abc} 1}$ & $23.61 \pm 2.03^{\mathrm{abc} 1}$ & $23.95 \pm 0.27^{\mathrm{ab} 1}$ \\
\hline Negative control & $150 \mathrm{mg} / \mathrm{kg} \mathrm{CCl}_{4}$ & $33.83 \pm 1.70^{\mathrm{cd} 2}$ & $34.92 \pm 0.29^{\mathrm{c} 21}$ & $36.01 \pm 0.49^{\mathrm{e} 1}$ & $38.39 \pm 2.20^{\mathrm{c} 1}$ & $41.91 \pm 1.44^{\mathrm{c} 1}$ \\
\hline \multirow[t]{3}{*}{ BCAE } & $200 \mathrm{mg} / \mathrm{kg}$ & $38.70 \pm 0.27^{\mathrm{c} 2}$ & $24.29 \pm 0.50^{\mathrm{ab} 1}$ & $28.96 \pm 0.30^{\text {bcd2 }}$ & $32.82 \pm 0.00^{\mathrm{abc} 3}$ & $28.44 \pm 0.59^{\mathrm{b} 2}$ \\
\hline & $400 \mathrm{mg} / \mathrm{kg}$ & $35.85 \pm 0.56^{c^{2}}$ & $31.17 \pm 3.87^{\mathrm{abc} 12}$ & $27.33 \pm 0.06^{\mathrm{abcd} 1}$ & $25.66 \pm 0.47^{\mathrm{a} 1}$ & $29.24 \pm 2.07^{\mathrm{bl}}$ \\
\hline & $800 \mathrm{mg} / \mathrm{kg}$ & $31.15 \pm 0.97^{\mathrm{abd} 2}$ & $32.34 \pm 2.59^{\mathrm{bc} 2}$ & $31.30 \pm 0.50^{\text {bcde2 }}$ & $27.94 \pm 2.02^{\mathrm{ab} 2}$ & $20.00 \pm 0.09^{\mathrm{al}}$ \\
\hline \multirow[t]{3}{*}{ BCME } & $200 \mathrm{mg} / \mathrm{kg}$ & $32.50 \pm 0.19^{\mathrm{bd} 12}$ & $29.87 \pm 2.89^{\mathrm{abcl}}$ & $32.02 \pm 1.24^{\text {cde } 12}$ & $39.39 \pm 3.38^{\mathrm{c} 2}$ & $31.74 \pm 0.41^{\mathrm{d} 12}$ \\
\hline & $400 \mathrm{mg} / \mathrm{kg}$ & $30.95 \pm 0.29^{\mathrm{abd} 12}$ & $24.35 \pm 2.24^{\mathrm{ab} 1}$ & $28.51 \pm 3.43^{\mathrm{bcd} 12}$ & $30.96 \pm 0.50^{\mathrm{abc} 12}$ & $32.02 \pm 1.61^{\mathrm{d} 2}$ \\
\hline & $800 \mathrm{mg} / \mathrm{kg}$ & $32.50 \pm 0.19^{\mathrm{bd} 12}$ & $22.17 \pm 0.98^{\mathrm{ab} 1}$ & $36.92 \pm 3.20^{\mathrm{e} 2}$ & $36.49 \pm 2.35^{\mathrm{bc} 2}$ & $27.07 \pm 6.50^{\mathrm{abd} 12}$ \\
\hline \multirow[t]{3}{*}{$\mathrm{BCCP}$} & $200 \mathrm{mg} / \mathrm{kg}$ & $35.66 \pm 1.27^{\mathrm{cd} 2}$ & $22.82 \pm 0.77^{\mathrm{ab} 1}$ & $20.15 \pm 0.18^{\mathrm{al}}$ & $39.61 \pm 2.78^{\mathrm{c} 2}$ & $22.81 \pm 1.35^{\mathrm{ab} 1}$ \\
\hline & $400 \mathrm{mg} / \mathrm{kg}$ & $33.31 \pm 0.50^{\mathrm{bd} 1}$ & $37.17 \pm 9.64^{\mathrm{cl}}$ & $33.84 \pm 3.46^{\mathrm{de} 1}$ & $34.51 \pm 3.49^{\mathrm{abc} 1}$ & $22.53 \pm 0.40^{\mathrm{ab} 1}$ \\
\hline & $800 \mathrm{mg} / \mathrm{kg}$ & $32.63 \pm 1.26^{\mathrm{bd} 12}$ & $28.31 \pm 0.87^{\mathrm{abc} 12}$ & $26.81 \pm 2.51^{\mathrm{abcd} 1}$ & $39.05 \pm 5.91^{\mathrm{c} 2}$ & $33.57 \pm 2.75^{\mathrm{d} 12}$ \\
\hline
\end{tabular}

Values represent mean \pm SEM of 3 observations. Values with in the same column with different alphabet superscripts differ significantly (p $<0.05$ ) between different concentrations at the same exposure duration, while values on the same row with different numeric superscripts differ significantly $(\mathrm{p}<0.05)$ between different exposure periods within the same concentration. $\mathrm{NC}=$ Normal control, $\mathrm{SL}=$ silymarin positive control, $\mathrm{CCl}_{4}=$ Carbon tetrachloride negative control, $\mathrm{BCAE}=$ Buchholzia coriacea aqueous extract, $\mathrm{BCME}=$ Buchholzia coriacea methanolic extract, $\mathrm{BCCP}=$ Buchholzia coriacea crude powder. 
and negative controls. Moreover, on the effects of treatment, there were significant increases $(p<0.05)$ in urea levels of those animals in silymarin, $\mathrm{CCl}_{4}$, crude seed powder, aqueous and methanolic extract groups after the induction of $\mathrm{CCl}_{4}$ when compared with the normal control at week 0 (Table 2). At week 2 and 4 , no significant differences $(\mathrm{p}<0.05)$ were observed in all the doses of the treatment groups when compared with the normal control except 800 $\mathrm{mg} / \mathrm{kg}$ BCME which produced significant increase $(\mathrm{p}<0.05)$ at week 2. Similarly, no significant differences $(p>0.05)$ were observed in the mean levels of urea in all the groups at week 6 when compared with control except the $\mathrm{CCl}_{4}$ group, 200 $\mathrm{mg} / \mathrm{kg} \mathrm{BCME}$ and 200 and $800 \mathrm{mg} / \mathrm{kg} \mathrm{BCCP}$ which indicated significant increase in urea levels when compared with the control. At week 8, significant increases $(\mathrm{p}<0.05)$ in urea levels were observed in those animals administered 200 and $400 \mathrm{mg} / \mathrm{kg}$ BCME, $800 \mathrm{mg} / \mathrm{kg} \mathrm{BCCP}$ and $\mathrm{CCl}_{4}$ group when compared with the normal control (Table 2).

Effects of graded doses of crude seed powder, aqueous and methanolic extracts of $B$. coriacea on uric acid level of hepatotoxic rats. There was no significant difference $(\mathrm{p}<0.05)$ in uric acid level in the negative control groups throughout the duration of the study (from week 2 to 8 ) compared with all other treatment groups (Table 3). Similarly, the normal control treatment group $(1 \mathrm{ml} / \mathrm{kg}$ normal saline) produced no significant differences $(\mathrm{p}>0.05)$ treated throughout the period of treatment. The silymarin group was observed to have a duration dependent significant reduction $(\mathrm{p}<0.05)$ in uric acid levels throughout the period of experiment whereas all the doses (200-400- and $800-\mathrm{mg} / \mathrm{kg}$ ) of $B$. coriacea crude seed powder, aqueous and methanolic extracts decrease significantly $(\mathrm{p}<0.05)$ from week 2 to 8 when compared with the normal and negative controls. Moreover, there were no significant difference $(p<0.05)$ in uric acid levels of those animals in silymarin, $\mathrm{CCl}_{4}$, crude seed powder, aqueous and methanolic extract groups after the induction of $\mathrm{CCl}_{4}$ when compared with the normal control at week 0 , except for $800 \mathrm{mg} / \mathrm{kg}$ BCAE (Table 3). At week 2, significant reduction $(\mathrm{p}<0.05)$ were observed in silymarin, $800 \mathrm{mg} / \mathrm{kg}$, BCAE, 400 $\mathrm{mg} / \mathrm{kg}$ BCME and 200 and $800 \mathrm{mg} / \mathrm{kg}$ BCCP, while others produced no significant effects $(\mathrm{p}>0.05)$ when compared with the control. Also, at week 4, no significant differences were observed in uric acid levels of all the groups when compared with the control. Similarly, at week 6 , except for animals in the silymarin treatment group and those administered 200 and $800 \mathrm{mg} / \mathrm{kg}$ BCAE and BCCP respectively which had significantly reduced $(\mathrm{p}<0.05)$ uric acid levels, other groups produced no significant effects ( $\mathrm{p}$ $>0.05$ ) when compared with the control. At week 8, significant decrease were observed in all the groups when compared with the control except for animals in $\mathrm{CCl}_{4}$ treatment group which produced significant increase $(\mathrm{p}<0.05)$ in uric acid levels (Table 3$)$.

Effects of graded doses of crude seed powder, aqueous and methanolic extracts of $B$. coriacea on blood urea nitrogen (BUN) level of hepatotoxic rats. The BUN level of negative control treatment group showed no significant difference $(\mathrm{p}>0.05)$ throughout the duration of the study (from week 2 to 8) compared with all other treatment groups (Table 4). Similarly, the BUN of the normal control treatment group (1 $\mathrm{ml} / \mathrm{kg}$ normal saline), the silymarin treatment group and other treatment groups administered different doses (200, 400 and 800 $\mathrm{mg} / \mathrm{kg}$ ) of B. coriacea crude seed powder, aqueous and methanolic extracts produced no significant differences $(p>0.05)$ throughout the period of treatments when compared with the normal control group except at dose level of $200 \mathrm{mg} / \mathrm{kg}$ BCAE which produced significant decrease at week 2 and $200 \mathrm{mg} / \mathrm{kg}$ BCCP that significantly decrease the BUN level from week 2 to 8 when compared with the control groups (Table 4). However, a minimal increase and decrease in BUN level was observed in some groups. Moreover, on the effects of treatment, there were no significant increase $(p>0.05)$ in BUN levels in animals in silymarin, $\mathrm{CCl}_{4}$, crude seed powder, aqueous and methanolic extract treatment 
groups when compared with the normal control at week 0 (Table 4) except $200 \mathrm{mg} / \mathrm{kg}, 400 \mathrm{mg} / \mathrm{kg}$ and $200 \mathrm{mg} / \mathrm{kg}$ doses of BCAE, BCME and BCCP respectively which produced significant increase ( $\mathrm{p}<$ $0.05)$ when compared with the control. Similarly, no significant difference $(\mathrm{p}>0.05)$ was observed in the mean values of $\mathrm{BUN}$ in $\mathrm{CCl}_{4}$ induced toxic rats in all the groups when compared with the normal control from week 2 to 8 (Table 4).

Table 3. Effects of graded doses of crude seed powder, aqueous and methanolic extracts of $B$. coriacea on uric acid level of hepatotoxic rats.

\begin{tabular}{|c|c|c|c|c|c|c|}
\hline \multirow[t]{2}{*}{ Treatments } & \multirow[t]{2}{*}{ Dosage } & \multicolumn{5}{|c|}{ Uric acid (mg/dl) } \\
\hline & & Week 0 & Week 2 & Week 4 & Week 6 & Week 8 \\
\hline Normal control & $1 \mathrm{ml} / \mathrm{kg}$ Normal saline & $12.36 \pm 0.2^{\mathrm{al}}$ & $12.94 \pm 2.82^{\mathrm{cl}}$ & $12.95 \pm 2.45^{\mathrm{abcl}}$ & $12.22 \pm 1.28^{\mathrm{cdel}}$ & $12.66 \pm 1.03^{\mathrm{bl}}$ \\
\hline Positive control & $200 \mathrm{mg} / \mathrm{kg}$ Silymarin & $20.78 \pm 5.59^{\mathrm{a} 3}$ & $10.72 \pm 1.79^{\mathrm{b} 12}$ & $9.32 \pm 0.08^{\mathrm{ab} 3}$ & $8.39 \pm 7.19^{\mathrm{ab} 23}$ & $2.86 \pm 0.33^{\mathrm{a}_{1}}$ \\
\hline Negative control & $150 \mathrm{mg} / \mathrm{kg} \mathrm{CCl} l_{4}$ & $22.36 \pm 4.67^{\mathrm{al}}$ & $23.66 \pm 0.10^{\mathrm{cl}}$ & $22.47 \pm 2.47^{\mathrm{cd} 1}$ & $26.48 \pm 0.59^{\mathrm{de} 1}$ & $28.48 \pm 5.22^{\mathrm{cl}}$ \\
\hline \multirow[t]{3}{*}{ BCAE } & $200 \mathrm{mg} / \mathrm{kg}$ & $20.03 \pm 0.10^{\mathrm{a3}}$ & $7.43 \pm 0.17^{\mathrm{abc} 2}$ & $8.02 \pm 0.60^{\mathrm{ab} 2}$ & $3.90 \pm 0.34^{\mathrm{a} 1}$ & $2.80 \pm 0.58^{\mathrm{a} 1}$ \\
\hline & $400 \mathrm{mg} / \mathrm{kg}$ & $18.84 \pm 0.81^{\mathrm{a3}}$ & $11.77 \pm 2.54^{\mathrm{bc} 2}$ & $7.32 \pm 2.18^{\mathrm{ab} 12}$ & $11.46 \pm 1.14^{\text {bcd2 }}$ & $3.93 \pm 1.03^{\mathrm{a} 1}$ \\
\hline & $800 \mathrm{mg} / \mathrm{kg}$ & $32.44 \pm 1.72^{\mathrm{b3}}$ & $6.54 \pm 0.68^{\mathrm{ab} 2}$ & $5.54 \pm 0.52^{\mathrm{ab} 12}$ & $4.29 \pm 0.14^{\mathrm{ab} 12}$ & $3.17 \pm 0.85^{\mathrm{a} 1}$ \\
\hline \multirow[t]{3}{*}{ BCME } & $200 \mathrm{mg} / \mathrm{kg}$ & $13.55 \pm 0.42^{\mathrm{a3}}$ & $6.88 \pm 0.48^{\mathrm{abc} 2}$ & $8.13 \pm 1.93^{\mathrm{ab} 2}$ & $5.80 \pm 0.14^{\mathrm{bc} 2}$ & $1.06 \pm 0.51^{\mathrm{a} 1}$ \\
\hline & $400 \mathrm{mg} / \mathrm{kg}$ & $13.09 \pm 0.68^{\mathrm{a2}}$ & $5.46 \pm 0.33^{\mathrm{ab} 1}$ & $4.75 \pm 0.69^{\mathrm{ab} 1}$ & $5.28 \pm 0.44^{\mathrm{abc} 1}$ & $2.93 \pm 4.32^{\mathrm{a} 1}$ \\
\hline & $800 \mathrm{mg} / \mathrm{kg}$ & $19.63 \pm 1.04^{\mathrm{a2}}$ & $8.32 \pm 4.54^{\mathrm{abc} 1}$ & $5.45 \pm 1.12^{\mathrm{ab} 1}$ & $5.15 \pm 0.38^{\mathrm{abc} 1}$ & $1.13 \pm 3.67^{\mathrm{a} 2}$ \\
\hline \multirow[t]{3}{*}{ ВССР } & $200 \mathrm{mg} / \mathrm{kg}$ & $21.81 \pm 6.54^{\mathrm{a} 2}$ & $4.53 \pm 1.17^{\mathrm{a} 1}$ & $3.45 \pm 1.30^{\mathrm{a} 1}$ & $4.94 \pm 0.24^{\mathrm{ab} 1}$ & $2.21 \pm 0.30^{\mathrm{a} 1}$ \\
\hline & $400 \mathrm{mg} / \mathrm{kg}$ & $16.38 \pm 2.01^{\mathrm{a3}}$ & $10.27 \pm 1.47^{\mathrm{abc} 2}$ & $8.24 \pm 1.87^{\mathrm{ab} 12}$ & $6.72 \pm 0.58^{\text {abc12 }}$ & $4.01 \pm 0.27^{\mathrm{a} 1}$ \\
\hline & $800 \mathrm{mg} / \mathrm{kg}$ & $18.64 \pm 0.70^{a 2}$ & $4.47 \pm 1.34^{\mathrm{a} 12}$ & $6.94 \pm 9.52^{\mathrm{bc} 12}$ & $4.30 \pm 0.72^{\mathrm{ab} 12}$ & $3.43 \pm 0.22^{\mathrm{a} 1}$ \\
\hline
\end{tabular}

Values represent mean \pm SEM of 3 observations. Values with in the same column with different alphabet superscripts differ significantly (p $<0.05$ ) between different concentrations at the same exposure duration, while values on the same row with different numeric superscripts differ significantly $(\mathrm{p}<0.05)$ between different exposure periods within the same concentration. $\mathrm{NC}=$ Normal control, $\mathrm{SL}=$ silymarin positive control, $\mathrm{CCl}_{4}=$ Carbon tetrachloride negative control, $\mathrm{BCAE}=$ Buchholzia coriacea aqueous extract, $\mathrm{BCME}=$ Buchholzia coriacea methanolic extract, $\mathrm{BCCP}=$ Buchholzia coriacea crude powder.

Table 4. Effects of graded doses of crude seed powder, aqueous and methanolic extracts of $B$. coriacea on blood urea nitrogen (BUN) level of hepatotoxic rats.

\begin{tabular}{|c|c|c|c|c|c|c|}
\hline \multirow[t]{2}{*}{ Treatments } & \multirow[t]{2}{*}{ Dosage } & \multicolumn{5}{|c|}{ Blood urea nitrogen $(\mathrm{mg} / \mathrm{dl})$} \\
\hline & & Week 0 & Week 2 & Week 4 & Week 6 & Week 8 \\
\hline Normal Control & $1 \mathrm{ml} / \mathrm{kg}$ Normal Saline & $12.68 \pm 0.54^{\mathrm{al}}$ & $12.71 \pm 1.89^{\mathrm{abc} 1}$ & $14.61 \pm 0.05^{\mathrm{abcd} 1}$ & $13.47 \pm 0.53^{\mathrm{ab} 1}$ & $13.23 \pm 0.85^{\mathrm{bcl}}$ \\
\hline Positive control & 200 mg/kg Silymarin & $13.92 \pm 1.89^{\mathrm{ab} 23}$ & $9.22 \pm 0.38^{\mathrm{a} 1}$ & $11.40 \pm 1.69^{\mathrm{ab} 12}$ & $12.70 \pm 0.95^{\mathrm{abc} 2}$ & $11.19 \pm 0.13^{\mathrm{ab} 12}$ \\
\hline Negative Control & $150 \mathrm{mg} / \mathrm{kg} \mathrm{CCl}_{4}$ & $14.24 \pm 1.52^{\mathrm{abcl}}$ & $11.64 \pm 0.14^{\mathrm{ab} 1}$ & $12.15 \pm 0.23^{\mathrm{abc} 1}$ & $14.93 \pm 1.03^{\mathrm{abc} 1}$ & $15.17 \pm 0.67^{\mathrm{ab} 1}$ \\
\hline \multirow[t]{3}{*}{$\mathrm{BCAE}$} & $200 \mathrm{mg} / \mathrm{kg}$ & $13.40 \pm 1.13^{\mathrm{ab} 2}$ & $11.34 \pm 0.23^{\mathrm{ab} 1}$ & $13.52 \pm 0.14^{\mathrm{bcd} 2}$ & $14.33 \pm 0.00^{\mathrm{abc} 2}$ & $13.28 \pm 0.27^{\mathrm{bc} 2}$ \\
\hline & $400 \mathrm{mg} / \mathrm{kg}$ & $16.74 \pm 0.26^{\mathrm{c} 2}$ & $14.56 \pm 1.80^{\mathrm{abc} 12}$ & $12.76 \pm 0.03^{\mathrm{bcd} 1}$ & $11.98 \pm 0.22^{\mathrm{al}}$ & $13.82 \pm 1.11^{\mathrm{bc} 12}$ \\
\hline & $800 \mathrm{mg} / \mathrm{kg}$ & $14.55 \pm 0.45^{\mathrm{abc2}}$ & $15.10 \pm 1.21^{\mathrm{bc} 2}$ & $14.62 \pm 0.23^{\mathrm{abcd} 2}$ & $12.96 \pm 0.87^{\mathrm{ab} 2}$ & $9.34 \pm 0.04^{\mathrm{a} 1}$ \\
\hline \multirow[t]{3}{*}{ BCME } & $200 \mathrm{mg} / \mathrm{kg}$ & $15.38 \pm 0.22^{\mathrm{bc} 12}$ & $13.95 \pm 1.35^{\mathrm{abcl}}$ & $14.95 \pm 0.58^{\mathrm{bcd} 12}$ & $14.38 \pm 1.88^{\text {abc12 }}$ & $14.82 \pm 0.19^{\mathrm{c} 12}$ \\
\hline & $400 \mathrm{mg} / \mathrm{kg}$ & $14.45 \pm 0.14^{\mathrm{abc} 12}$ & $11.37 \pm 1.05^{\mathrm{ab} 1}$ & $13.31 \pm 1.60^{\mathrm{bcd} 12}$ & $14.46 \pm 0.23^{\text {abc12 }}$ & $13.95 \pm 0.75^{\mathrm{c} 12}$ \\
\hline & $800 \mathrm{mg} / \mathrm{kg}$ & $15.18 \pm 0.09^{\text {abc12 }}$ & $12.35 \pm 0.46^{\text {abc12 }}$ & $17.25 \pm 1.50^{\mathrm{d} 2}$ & $17.04 \pm 1.10^{\mathrm{bc} 2}$ & $12.64 \pm 3.03^{\mathrm{abc} 12}$ \\
\hline \multirow[t]{3}{*}{$\mathrm{BCCP}$} & $200 \mathrm{mg} / \mathrm{kg}$ & $16.65 \pm 0.59^{c^{2}}$ & $10.66 \pm 0.36^{\mathrm{ab} 1}$ & $9.41 \pm 0.08^{\mathrm{a} 1}$ & $12.50 \pm 1.30^{\mathrm{ab} 1}$ & $10.65 \pm 0.63^{\mathrm{ab} 1}$ \\
\hline & $400 \mathrm{mg} / \mathrm{kg}$ & $15.29 \pm 0.14^{\mathrm{abc} 1}$ & $17.34 \pm 4.49^{\mathrm{cl}}$ & $15.81 \pm 1.61^{\mathrm{cd} 1}$ & $16.12 \pm 1.63^{\mathrm{abc} 1}$ & $10.47 \pm 0.19^{\mathrm{ab} 1}$ \\
\hline & $800 \mathrm{mg} / \mathrm{kg}$ & $15.24 \pm 0.59^{\mathrm{abc} 1}$ & $13.22 \pm 0.40^{\mathrm{abc} 12}$ & $12.52 \pm 1.17^{\mathrm{abcd} 1}$ & $14.24 \pm 2.76^{\mathrm{abc} 1}$ & $15.68 \pm 1.28^{\mathrm{cl}}$ \\
\hline
\end{tabular}

Values represent mean \pm SEM of 3 observations. Values with in the same column with different alphabet superscripts differ significantly (p $<0.05)$ between different concentrations at the same exposure duration, while values on the same row with different numeric superscripts differ significantly $(\mathrm{p}<0.05)$ between different exposure periods within the same concentration. $\mathrm{NC}=$ Normal control, $\mathrm{SL}=$ silymarin positive control, $\mathrm{CCl}_{4}=$ Carbon tetrachloride negative control, $\mathrm{BCAE}=$ Buchholzia coriacea aqueous extract, $\mathrm{BCME}=$ Buchholzia coriacea methanolic extract, $\mathrm{BCCP}=$ Buchholzia coriacea crude powder. 
Effects of graded doses of crude seed powder, aqueous and methanolic extracts of $B$. coriacea on total protein level of hepatotoxic rats. The hepatotoxic rats in positive control group had duration independent significant increase $(\mathrm{p}<0.05)$ in total protein throughout the period of the experiment when compared with week 0 . Similarly, a duration independent significant increase $(\mathrm{p}<0.05)$ in total protein level of $\mathrm{CCl}_{4}$ induced toxic rats were observed in all the doses $(200,400$ and $800 \mathrm{mg} / \mathrm{kg}$ ) of BCAE and BCME throughout the period of the study, while that of BCCP significantly increased only at week 8 when compared with the week 0 . However, on the effects of treatment, the silymarin, $\mathrm{CCl}_{4}$, crude seed powder, aqueous and methanolic extract groups produced duration independent significant reduction $(p<0.05)$ in total protein level levels after the induction of $\mathrm{CCl}_{4}$ when compared with the normal control at week 0 except $400 \mathrm{mg} / \mathrm{kg}$ BCCP. Whereas no significant differences $(p>0.05)$ were observed at week 2, 4 and 8 when compared with the control, but at week 6 , only those administered $800 \mathrm{mg} / \mathrm{kg}$ BCAE produced significant increase $(\mathrm{p}<0.05)$ in total protein levels of $\mathrm{CCl}_{4}$ induced toxic rats when compared with the control while the rest of the groups did not exhibit any significant change (Table 5).

Table 5. Effects of graded doses of crude seed powder, aqueous and methanolic extracts of $\boldsymbol{B}$. coriacea on total protein level of hepatotoxic rats.

\begin{tabular}{|c|c|c|c|c|c|c|}
\hline \multirow[t]{2}{*}{ Groups } & \multirow[t]{2}{*}{ Treatments } & \multicolumn{5}{|c|}{ Total protein (g/dl) } \\
\hline & & Week 0 & Week 2 & Week 4 & Week 6 & Week 8 \\
\hline Normal control & $1 \mathrm{ml} / \mathrm{kg}$ Normal Saline & $5.27 \pm 0.17^{\mathrm{cl}}$ & $5.48 \pm 0.12^{\text {abcl }}$ & $5.49 \pm 0.18^{\mathrm{bc} 1}$ & $5.47 \pm 0.23^{\text {bc1 }}$ & $5.98 \pm 0.46^{\mathrm{a} 1}$ \\
\hline Positive ontrol & 200 mg/kg Silymarin & $4.36 \pm 0.24^{\mathrm{ab} 1}$ & $5.65 \pm 0.17^{\mathrm{bc} 2}$ & $5.36 \pm 0.07^{\mathrm{bc} 2}$ & $5.61 \pm 0.10^{\mathrm{bcd} 2}$ & $5.43 \pm 0.17^{\mathrm{a} 2}$ \\
\hline Negative control & $150 \mathrm{mg} / \mathrm{kg} \mathrm{CCl} 4$ & $4.41 \pm 0.19^{\mathrm{ab} 1}$ & $4.71 \pm 0.17^{\mathrm{ab} 1}$ & $4.52 \pm 0.19^{\mathrm{bc} 1}$ & $4.50 \pm 0.18^{\text {bcd } 1}$ & $5.05 \pm 0.34^{\mathrm{a} 1}$ \\
\hline \multirow[t]{3}{*}{ BCAE } & $200 \mathrm{mg} / \mathrm{kg}+\mathrm{CCl}_{4}$ & $4.52 \pm 0.16^{\mathrm{ab} 1}$ & $5.49 \pm 0.33^{\mathrm{abc} 2}$ & $5.79 \pm 0.04^{\mathrm{c} 2}$ & $5.29 \pm 0.18^{\text {bc } 2}$ & $5.43 \pm 0.17^{\mathrm{a} 2}$ \\
\hline & $400 \mathrm{mg} / \mathrm{kg}+\mathrm{CCl}_{4}$ & $4.44 \pm 0.02^{\mathrm{ab} 1}$ & $5.42 \pm 0.43^{\mathrm{abc} 2}$ & $5.48 \pm 0.01^{\mathrm{bc} 2}$ & $5.63 \pm 0.03^{\mathrm{cd} 2}$ & $5.40 \pm 0.21^{\mathrm{a} 2}$ \\
\hline & $800 \mathrm{mg} / \mathrm{kg}+\mathrm{CCl}_{4}$ & $4.23 \pm 0.01^{\mathrm{a} 1}$ & $4.62 \pm 0.39^{\mathrm{a} 12}$ & $5.34 \pm 0.09^{\mathrm{bc} 23}$ & $6.10 \pm 0.34^{\mathrm{d} 3}$ & $5.18 \pm 0.35^{\mathrm{a} 23}$ \\
\hline \multirow[t]{3}{*}{ BCME } & $200 \mathrm{mg} / \mathrm{kg}+\mathrm{CCl}_{4}$ & $4.44 \pm 0.19^{\mathrm{ab} 1}$ & $5.34 \pm 0.07^{\mathrm{abc} 23}$ & $5.83 \pm 0.03^{\mathrm{c} 3}$ & $5.04 \pm 0.29^{\mathrm{b} 12}$ & $5.38 \pm 0.35^{\mathrm{a} 23}$ \\
\hline & $400 \mathrm{mg} / \mathrm{kg}+\mathrm{CCl}_{4}$ & $4.27 \pm 0.17^{\mathrm{ab} 1}$ & $5.86 \pm 0.22^{\mathrm{c} 2}$ & $5.60 \pm 0.24^{\mathrm{c} 2}$ & $5.67 \pm 0.03^{\mathrm{cd} 2}$ & $5.67 \pm 0.29^{\mathrm{a} 2}$ \\
\hline & $800 \mathrm{mg} / \mathrm{kg}+\mathrm{CCl}_{4}$ & $4.44 \pm 0.02^{\mathrm{ab} 1}$ & $5.01 \pm 0.46^{\mathrm{abc} 12}$ & $5.45 \pm 0.23^{\text {bc2 }}$ & $5.61 \pm 0.00^{\mathrm{cd} 2}$ & $5.53 \pm 0.34^{\mathrm{a} 2}$ \\
\hline \multirow[t]{3}{*}{$\mathrm{BCCP}$} & $200 \mathrm{mg} / \mathrm{kg}+\mathrm{CCl}_{4}$ & $4.53 \pm 0.19^{\mathrm{ab} 1}$ & $4.90 \pm 0.36^{\mathrm{abc} 12}$ & $5.03 \pm 0.22^{\mathrm{b} 12}$ & $5.11 \pm 0.03^{\mathrm{bc} 12}$ & $5.59 \pm 0.20^{\mathrm{a} 2}$ \\
\hline & $400 \mathrm{mg} / \mathrm{kg}+\mathrm{CCl}_{4}$ & $4.98 \pm 0.43^{\mathrm{bc} 1}$ & $5.40 \pm 0.18^{\mathrm{abc} 12}$ & $5.54 \pm 0.17^{\mathrm{bc} 12}$ & $5.35 \pm 0.17^{\mathrm{bc} 12}$ & $5.58 \pm 0.27^{\mathrm{a} 2}$ \\
\hline & $800 \mathrm{mg} / \mathrm{kg}+\mathrm{CCl}_{4}$ & $4.49 \pm 0.34^{\mathrm{ab} 1}$ & $4.90 \pm 0.21^{\mathrm{abc} 1}$ & $5.48 \pm 0.19^{\mathrm{bc} 1}$ & $5.55 \pm 0.04^{\text {bcd } 1}$ & $5.49 \pm 0.25^{\mathrm{a} 1}$ \\
\hline
\end{tabular}

Values represent mean \pm SEM of 3 observations. Values with in the same column with different alphabet superscripts differ significantly (p $<0.05$ ) between different concentrations at the same exposure duration, while values on the same row with different numeric superscripts differ significantly $(\mathrm{p}<0.05)$ between different exposure periods within the same concentration. NC $=\mathrm{Normal}$ control, SL $=$ silymarin positive control, $\mathrm{CCl}_{4}=$ Carbon tetrachloride negative control, $\mathrm{BCAE}=$ Buchholzia coriacea aqueous extract, $\mathrm{BCME}=$ Buchholzia coriacea methanolic extract, $\mathrm{BCCP}=$ Buchholzia coriacea crude powder.

Serum urea, blood urea nitrogen, uric acid and creatinine are often regarded as reliable kidney function markers or as essential measure of renal function status. ${ }^{24}$ Thus, elevation in the serum concentration of these markers are indicative of renal injury. ${ }^{24}$ Creatinine is spontaneously generated by cyclic derivative of creatine. It is chiefly filtered out of the blood by the kidney through glomerular filtration and proximal tubular secretion. There is little or no tubular reabsorption of creatinine in the body. However, if the filtration ability of kidney is impaired, there will be rise in serum creatinine levels. This suggested diminished ability of the kidney to filter these waste products from the blood. ${ }^{25}$ Urea is a by-product of metabolism of protein, which is generated in the liver, then filtered from the blood and excreted in the urine by the kidney. The BUN test measures the nitrogen amount contained in the 
urea in blood sample. High BUN in the serum indicates kidney dysfunction. It is therefore reported that serum concentration of creatinine, urea, uric acid and BUN depends on the glomerular filtration. ${ }^{26}$ Thus, the rise in creatinine levels and other kidney function markers of the experimental rats estimated in this study after induction of $\mathrm{CCl}_{4}$ at week 0 is an indication that $\mathrm{CCl}_{4}$ had negatively affected the administration glomerular filtration and proximal tubular of the kidney. Nevertheless, after administering the extracts, the creatinine and uric acid levels reduced significantly from week 2 to 8 when compared with the $\mathrm{CCl}_{4}$ and normal control, while the total protein increased significantly $(\mathrm{p}<0.05)$. This suggests that $B$. coriacea crude seed powder, methanolic and aqueous extracts may have nephroprotective properties in dose and duration independent manner. Similarly, the significant decrease observed in $200 \mathrm{mg} / \mathrm{kg}$ BCAE and BCCP in urea and BUN levels suggested that the extracts could be more effective if administered at a low dose. However, the nephroprotective effects could be attributed to the presence of phytochemicals like flavonoids and tannins which act as antioxidants. ${ }^{27,28}$

\section{CONCLUSION}

The study has demonstrated that B. coriacea crude seed powder, methanolic and aqueous extracts are safe for consumption since it does not cause any adverse effect on the rat kidney and could be used in the management of nephrotoxicity. We therefore, suggest that, there is the need for further studies on the B. coriacea seed to fully understand its stability and suitability in clinical trials and also to isolate the individual phytochemical present in B. coriacea and determine the ones responsible for the its nephroprotective ability.

Competing interests: The authors declare that they have no competing interests.

Funding: No internal or external funding was obtained for this study.

Authors' contributions: JEE designed the experiment, supervised the study and wrote the manuscript. GCU performed the experiments and participated in writing up the manuscript. CLO and JVE provided the plant material and contributed ideas. JIO and EIN analyzed and interpreted the collected data. All authors read and approved the manuscript for publication.

\section{ACKNOWLEDGEMENT}

The authors acknowledged Mr. A.O. Ozioko of Bioresources Development and Conservation Programme (BDCP), Nsukka, Enugu State, Nigeria for the identification of the plants.

\section{REFERENCES}

1. Keay, R.W.J. 1989. Trees of Nigeria. Clarendon Press, Oxford, London.

2. Grieve, M. and Leyel, C.F. 1984. A Modern Herbal. Penguin Harmondsworth, England.

3. Culpeper, N. 1995. Culpeper's Complete Herbal: A Book of Remedies of Ancient Ills. (The Word's Worth Reference Collection Library). Contemporary Publishing Company, USA.

4. Holt, J.G., Krieg, N.R., Sneath, P.H.A., Stanley, J.T. and Williams, S.T. 1994. Bergey's Manual of Systematic Bacteriology, $4^{\text {th }}$ Edition, William and Wilkins Company, Baltimore, Maryland.

5. Anowi, C.F., Ezugwu, C.O., Onyekaba, T.U. and UtohNedosa, U.A.2012. Evaluation of antimicrobial properties of diethylether extract of the root-bark of Buchholzia coriacea (Capparaceae). Asian J. Pharm. Life Sci. 2, 226-233.

6. Mbata, T. I., Duru, C. M. and Onwumelu, H. A. 2009. Antibacterial activity of crude seed extract of Buccholzia coriacea E. on some pathogenic bacterials. J. Dev. Biol.Tissu. Eng 1, 1-5.

7. Cruickshank, R., Daguid, J.P., Marnino, B.P. and Swain, R.H. 1980. Medical Microbiology. $12^{\text {th }}$ Edition, Churchill, Livingstone, London.

8. Ajaiyeoba, E.O., Onocha, P.A. and Olarenwaju, O.T. 2001. In vitro anthelmintic properties of Buchholzia coriaceae and Gynandropsisgynandra extracts. Pharm. Biol. 39, 217-220.

9. Nweze, N.E. and Asuzu, I.U. 2006. The anthelmintic effects of Buchholzia coriacea seed. Niger. Vet. J. 27, 60-65.

10. Oluseyi, E.O. and Onyeoziri, N.F. 2009. Preliminary studies on the antimicrobial properties of Buchholzia coriacea. Afr. J. Biotechnol. 8, 472-474.

11. Adisa, R.A., Choudhary, M.I. and Olorunsogo, O.O. 2011. Hypoglycemic activity of Buchholzia coriacea (Capparaceae) seeds in streptozotocin-induced diabetic rats and mice. Exp. Toxicol. Pathol. 63, 619- 625. 
12. Adjanohoun, J.E., Aboubakar, N., Dramane, K., Ebot, M.E., Ekpere, J.A., Enoworock, E.G., Focho, D., Gbile, Z.O., Kamanyi, A., Kamsu-Kom, J. and Keita, A. 1996. Traditional medicine and pharmacopoeia: contribution to ethnobotanical and floristic studies in Cameroon. Scientific, Technical and Research Commission, Organization of African Unity, Nigeria.

13. Adediwura, F.J., Omonike, O., Olamide, A. and Oluwatosin, E. 2011. Larvicidal effect of the pet. ether, chloroform fractions and methanol extract of Buchholzia coriacea Engle seed. Int. J. Pharm. Sci. Res. 2, 1736-1739.

14. Ezeja, M.I., Ezeigbo, I.I. and Madubuike, K.G. 2011. Analgesic activity of the methanolic seed extract of Buchholziacoriacea. Res. J. Pharm. Biol. Chem. Sci. 2, 187193.

15. Okere, O.S., Iliemene, U.D., Tese, T., Mubarak, L. and Olowoniyi, O.D. 2014. Proximate analysis, phytochemical screening and antitrypanocidal potentials of Buchholzia coriacea in Trypanosoma bruceibrucei-infected mice. IOSR J. Pharm. Biol. Sci. 9, 69-77.

16. Derrell, C. 1996. Guide for the Care and Use of Laboratory Animals. Institute of Laboratory Animal Resources, National Academy Press, Washington DC, USA.

17. Manikandaselvi, S., Ezhilarasi, S. and Vaithehi, R. 2012. Modulation of lysosomal enzymes activity by Carica papaya Linn. and Solanum torvum Linn. in carbon tetrachloride vapour induced liver damage in rats. J. Chem. Pharm. Res. 4, 1235-1238.

18. Hoff, J. 2000. Methods of blood collection in the mouse. Lab. Anim. 29, 50-51.

19. Folin, O. 1933. Standardized methods for the determination of uric acid in unlaked blood and urine. J. Biol. Chem. 101, 111-125.
20. Peters, J.H. 1942. The determination of creatinine and creatine in blood and urine with the photoelectric colorimeter. J. Biol. Chem. 146, 179-186.

21. Kaplan, A. 1965. Urea nitrogen and urinary ammonia. In: Meites, S. (Ed.), Standard Methods of Clinical Chemistry. Academic Press, New York. pp. 245-256.

22. Sood, R. 2006. Medical Laboratory Technology. Jaypee Brothers Medical Publishers Limited. New Delhi, India.

23. Duncan, D.B. 1955. Multiple range and multiple F tests. Biometrics, 11, 1-42.

24. Adelman, R.D., Spangler, W.L., Beasom, F., Ishizaki, G. and Conzelman, G.M. 1979. Furosemide enhancement of experimental gentamicin nephrotoxicity: comparison of functional and morphological changes with activities of urinary enzymes. J. Infect. Dis. 140, 342-352.

25. Hitesh, C. and Nageswara, S.B.R.R. 2013. Experimental appraisal of nephro-protective activity of Varunadi loha. Int. Ayurvedic Med. J. 1, 1-8.

26. Sakr, S.A. and Al-Amoudi, W.M. 2012. Effect of leave extract of Ocimumbasilicum on deltamethrin induced nephrotoxicity and oxidative stress in albino rats. J. App. Pharm. Sci. 2, 22-27.

27. Olagunju, J.A., Adeneye, A.A., Fagbohunka, B.S., Bisuga, N.A., Ketiku, A.O., Benebo, A.S., Olufowobi, O.M., Adeoye, A.G., Alimi, M.A. and Adeleke, A.G. 2009. Nephroprotective activities of the aqueous seed extract of Carica papaya Linn. in carbon tetrachloride induced renal injured Wistar rats: a dose-and time-dependent study. Biol. Med. 1, 11-19.

28. 28 Nale, I.P., More, P.R., More, B.K., Ghumare, B.C., Shendre, S.B. and Mote, C.S. 2012. Protective effect of Carica papaya 1. seed extract in gentamicin induced hepatotoxicity and nephrotoxicity in rats. Int. J. Pharm. Bio Sci. 3, 508-515. 